\title{
Conventional and organic cropping systems at Suitia IV: weeds
}

\author{
RAIMO KAUPPILA \\ University of Helsinki, Department of Crop Husbandry \\ SF-00710 Helsinki, Finland
}

\begin{abstract}
At Suitia, Southern Finland, weed populations in different crop rotations at conventional and organic cropping systems were investigated in 1982-1988.

The number of weeds and the dry matter yields of weeds were greater in organic cropping (on average 324 weeds $/ \mathrm{m}^{2}$ and $425 \mathrm{~kg} \mathrm{DM} / \mathrm{ha}$ ) compared to conventional cropping ( 94 weeds $/ \mathrm{m}^{2}$ and $61 \mathrm{~kg} \mathrm{DM} / \mathrm{ha}$ ). There were least weeds in the conventionally cultivated ley. The first year, clover ley in organic cropping prevented the growth of weeds as well as the grass ley in conventional cropping. Overwintering damages in organically cultivated leys increased the amounts of weeds in the following ley years.

Organically cultivated winter wheat reduced the amount and weight of weeds almost as well as conventionally cultivated winter wheat although its biomass was three-fourths of the conventionally cultivated winter wheat. The biomass of organically cultivated barley later on in the rotations was only one-fifth of the conventionally cultivated barley and had five times more weeds.

In conventional cropping, the number of weeds in almost all weed species was decreased or stayed at the same level during the experiment. In organic cropping, the number of most weeds in weed species increased from the level for 1982. Most increased Stellaria media, Fallopia convolvulus, Lamium sp and Chenopodium album.
\end{abstract}

Index words: weeds, cropping systems, organic cropping, conventional cropping.

\section{Introduction}

Weeds are postulated to be one of the most difficult problems in organic farming, where herbicides are not used. Possible substitutive methods for herbicides are, for instance, crop rotation, careful ploughing, fallowing, delayed cultivation before sowing and stub- ble cultivation. Harrowing of the cereal field surface before or after the emergence of seedlings is also used in organic cropping.

The cereal species, the previous crop, the fertilisation method and the time of practise in organic cropping have an essential effect on the number and biomass of weeds and on the abundance of different weed species (MELA 
1988). The aims of this investigation, as a part of a larger project (HANNUKKALA et al. 1990), were to clarify the effects of different crop rotations in different cropping systems on the amount of weeds and weed species.

\section{Material and methods}

\section{Experimental field}

The field consists of about 6 ha (net area) of arable land typical of the grain producing areas of Southern Finland. In 1982, the field was divided into three blocks, and each of these into eight plots. Crop rotations A and B were cultivated conventionally, C and D organically. In the year 1983 the plots were divided into two, phase a and phase $b$, where phase b skipped three years in the six-year rotations. Table 1 shows the crop sequences in 1982-1988.

\section{Weed control}

In conventional cropping weeds were controlled with herbicides, while no chemicals were used in organic cropping. A more detailed description of the herbicide treatments and other cultivation methods are given in HanNUKKala et al. 1990.

\section{Weed and plant stand sampling}

The time and amount of weed and crop sampling varied slightly between years. An attempt was made to take the samples when cereals were heading or a little later. Samples were taken from leys before the first cut. Sampling took from one to three days. Weed and crop samples from winter wheat and leys were taken yearly between the 20th of June and the 12 th of July and from spring sown species between the 4th and 29th of July. The sample areas in conventional cropping had been treated with herbicides.

Table 1. Crop sequences at Suitia in 1982-1988.

Crop sequences

\begin{tabular}{|c|c|c|c|c|c|c|c|}
\hline $\begin{array}{l}\text { Phase a } \\
\text { Phase b } \\
\text { System }\end{array}$ & $\begin{array}{c}1982 \\
1982 \\
->\end{array}$ & $\begin{array}{r}1983 \\
-> \\
1986\end{array}$ & $\begin{array}{c}1984 \\
-> \\
1987\end{array}$ & $\begin{array}{c}1985 \\
-> \\
1988\end{array}$ & $\begin{array}{l}1986 \\
1983\end{array}$ & \begin{tabular}{l}
1987 \\
\hdashline---- \\
1984
\end{tabular} & $\begin{array}{l}1988 \\
1985\end{array}$ \\
\hline A1 & barley & barley & barley & barley & arley & arley & $y$ \\
\hline $\begin{array}{l}\mathrm{A} 2 \\
\mathrm{~A}\end{array}$ & $\begin{array}{l}------ \\
\text { barley }\end{array}$ & $\begin{array}{l}------- \\
\text { oats }\end{array}$ & $\begin{array}{l}------- \\
\text { spring } \\
\text { wheat }\end{array}$ & $\begin{array}{l}------ \\
\text { barley }\end{array}$ & $\begin{array}{l}------- \\
\text { winter } \\
\text { wheat }\end{array}$ & barley & $\begin{array}{l}------ \\
\text { barley }\end{array}$ \\
\hline $\begin{array}{l}\text { А } 3 \\
\text { L }\end{array}$ & $\begin{array}{l}------ \\
\text { barley }\end{array}$ & $\begin{array}{l}------- \\
\text { oats }+ \\
\text { V.faba }\end{array}$ & $\begin{array}{l}------ \\
\text { potato }\end{array}$ & $\begin{array}{l}------ \\
\text { barley }\end{array}$ & $\begin{array}{l}------- \\
\text { winter } \\
\text { wheat }\end{array}$ & $\begin{array}{l}\text { turnip } \\
\text { rape }\end{array}$ & barley \\
\hline $\begin{array}{l}\mathrm{B} \\
--------------1\end{array}$ & $\begin{array}{l}------ \\
\text { barley } \\
+ \text { leys. }\end{array}$ & ley & $\begin{array}{l}\text { ley } \\
\text { le----- }\end{array}$ & $\begin{array}{l}------- \\
\text { ley }\end{array}$ & $\begin{array}{l}\text { winter } \\
\text { wheat }\end{array}$ & $\begin{array}{l}------ \\
\text { oats }\end{array}$ & $\begin{array}{l}\text { barley } \\
\text { +leys. }\end{array}$ \\
\hline--- & ------- & -・-ン--- & ------1 & -ン--ン-- & ------- & ------- & -ー-ー--- \\
\hline $\begin{array}{l}\mathrm{C} 1, \mathrm{C} 2 \\
-\mathrm{D} 1, \mathrm{D} 2\end{array}$ & $\begin{array}{l}\text { barley } \\
+ \text { clover } \\
------ \\
\text { barley } \\
+ \text { leys. }\end{array}$ & $\begin{array}{l}\text { barley } \\
+ \text { clover } \\
------- \\
\text { ley }\end{array}$ & $\begin{array}{l}\text { potato } \\
------- \\
\text { annual } \\
\text { ley } \star \text { ) }\end{array}$ & $\begin{array}{l}\text { Persian } \\
\text { clover } \\
------ \\
\text { annual } \\
\text { ley }\end{array}$ & $\begin{array}{l}\text { winter } \\
\text { wheat } \\
\text { winter } \\
\text { winteat }\end{array}$ & $\begin{array}{l}\text { oats + } \\
\text { V.faba } \\
------ \\
\text { oats }\end{array}$ & $\begin{array}{l}\text { barley } \\
+ \text { clover } \\
------ \\
\text { barley } \\
+ \text { leys. }\end{array}$ \\
\hline
\end{tabular}

* supplemented with additional seed in 1987 only 
Several small samples were taken from randomly chosen points in the plots. The area of one sample was usually $0.25 \mathrm{~m}^{2}$, and the total area per plot varied yearly from 0.5 to 1.0 $\mathrm{m}^{2}$. The shoots of the cultivated crop were first cut at the field surface. Weed species were indentified, and all weeds were counted. The dry weights were determined by drying for 24 hours at $+105^{\circ} \mathrm{C}$. The results are reported as numbers $/ \mathrm{m}^{2}$ or $\mathrm{kg} / \mathrm{ha}$.

\section{Statistical analyses}

The significance of differences were tested with the ANOVA model as described by HanNukKala et al. 1990.

\section{Results}

The rotations were combined to four cropping sequences because there were no significant differences between the weeds in the rotations A1-A3, C1 and C2 or D1 and D2. The new groups were:

$\mathrm{A}=$ conventional plant production

$\mathrm{B}=$ conventional plant production on

a cattle farm

$\mathrm{C}=$ organic plant production

$\mathrm{D}=$ organic plant production on a cattle farm

The results are reported as averages for the two phases ( $a$ and $b$ ) because there were no significant differences between the phases.

\section{Number of weeds}

In the first trial year (1982) barley was grown in all plots. In sequences $\mathrm{B}, \mathrm{C}$ and $\mathrm{D}$, ley crops were sown in addition, under the cereals. The number of weeds was slightly higher in organic cropping than in conventional cropping (Table 2).

Making comparisons between various crop rotations and between years is difficult because the cultivated crops varied often during the six-year-long rotations. Considering all rotations and trial years, the number of weeds were, however, the smallest $\left(9-56\right.$ weeds $/ \mathrm{m}^{2}$ ) during the ley years in conventional cropping.

The number of weeds in organic cropping was usually manifold that in conventional cropping. The number of weeds was smallest (62 weeds $/ \mathrm{m}^{2}$ ) in the first ley year. In the second and third year ley there were, however, over 400 weeds $/ \mathrm{m}^{2}$. In the organically cultivated potato crop the number of weeds was relatively small (162 weeds $\left./ \mathrm{m}^{2}\right)$.

In 1986 (phase a) and 1983 (phase b), winter wheat was grown in all plots except the barley monoculture plot (A1). In conventional cropping the number of weeds in winter wheat did not differ much from the other years. In organic cropping the number of weeds was, however, noticeably smaller than in the other years, being only slightly higher than in conventionally cultivated wheat stands.

In 1988 (phase a) and 1985 (phase b), barley was grown in all the plots. In organic cropping the number of weeds was over five times higher than in conventional cropping. In conventional cropping the number of weeds had decreased, and in organic cropping it had increased noticeably compared with the number of weeds at the beginning of the trial.

Table 2. Number of weeds per square metre in conventional and organic cropping in 1982-1988. For crop sequences A to D and years, see Table 1.

\begin{tabular}{lrrrrrrrr}
\hline Years & 82 & $83 / 86$ & $84 / 87$ & $85 / 88$ & $86 / 83$ & $87 / 84$ & $88 / 85$ & $x$ \\
\hline Conventional & & & & & & & & \\
A & 96 & 246 & 112 & 46 & 103 & 109 & $69^{\mathrm{a}}$ & 112 \\
B & 131 & 21 & 56 & 9 & 86 & 117 & $105^{\mathrm{a}}$ & 75 \\
Organic & & & & & & & \\
C & 152 & 659 & 162 & 426 & 142 & 303 & $505^{\mathrm{b}}$ & 336 \\
D & 204 & 62 & 443 & 432 & 159 & 290 & $558^{\mathrm{b}}$ & 311 \\
\hline
\end{tabular}




\section{Weed dry weights}

The changes in weed dry weights followed the changes in the number of weeds. The dry weight of weeds was smallest $(16-67 \mathrm{~kg} / \mathrm{ha})$ in conventionally cultivated leys and highest $(1200-1280 \mathrm{~kg} / \mathrm{ha})$ in the second and third year ley of organic cropping (Table 3). The individual weed dry weights were usually higher in organic cropping.

\section{Weed species}

The weed species were determined yearly from all plots. The number of weeds in different species at the beginning and at the end of the original crop rotation (phase a) are reported. In both years, barley was the cultivated crop. Up to 1988, the total number of weeds decreased in conventional cropping and increased in organic cropping (Table 4).
In 1982, Fumaria officinalis was the most common weed species in all rotations. The differences between the rotations were, however, rather small $\left(56-76\right.$ weeds $\left./ \mathrm{m}^{2}\right)$. Stellaria media, Chenopodium album, Fallobia convolvulus and Lamium sp. were the next common weed species. The number of weeds listed above were slightly higher in organic cropping than in conventional cropping.

Up to 1988 , the number of weeds in nearly all weed species had decreased or stayed stable in conventional cropping. Elymus repens had, however, clearly increased in the cattle farm crop rotation. Organic cropping had increased the number of most weeds in weed species as compared to 1982. The increase was highest for the species of Stellaria media, Fallopia convolvulus, Lamium sp. and Chenopodium album.

In conventional cropping in 1988 , nine

Table 3. Dry matter yields $(\mathrm{kg} / \mathrm{ha})$ of weeds in conventional and organic cropping in 1982-1988. For crop sequences A to D and years, see Table 1 .

\begin{tabular}{lrrrrrrrr}
\hline Years & 82 & $83 / 86$ & $84 / 87$ & $85 / 88$ & $86 / 83$ & $87 / 84$ & $88 / 85$ & $x$ \\
\hline Conventional & & & & & & & & \\
A & 32 & 127 & 168 & 42 & 52 & 68 & $7^{\text {a }}$ & 71 \\
B & 43 & 34 & 67 & 16 & 90 & 52 & $51^{\text {a }}$ & 50 \\
Organic & 110 & 338 & 390 & 1141 & 39 & 330 & $298^{\text {b }}$ & 378 \\
C & 142 & 26 & 1200 & 1280 & 63 & 279 & $310^{\text {b }}$ & 471 \\
D & & & & & & & & \\
\hline
\end{tabular}

Table 4. Number of weeds in different weed species per square metre in conventional and organic cropping in 1982 and 1988. For crop sequences $\mathrm{A}$ to $\mathrm{D}$, see Table 1.

\begin{tabular}{|c|c|c|c|c|c|c|c|c|}
\hline Crop sequence & A & & B & & $\mathrm{C}$ & & D & \\
\hline Species & 82 & 88 & 82 & 88 & 82 & 88 & 82 & 88 \\
\hline Chenopodium album & 4 & 0 & 6 & 0 & 8 & 28 & 24 & 21 \\
\hline Elymus repens & 0 & 0 & 0 & 18 & 0 & 2 & 0 & 9 \\
\hline Fallopia convolvulus & 6 & 2 & 4 & 1 & 16 & 69 & 23 & 53 \\
\hline Fumaria officinalis & 68 & 28 & 76 & 31 & 72 & 72 & 56 & 75 \\
\hline Galeopsis sp & 1 & 1 & 2 & 2 & 3 & 8 & 4 & 5 \\
\hline Galium $s p$ & 3 & 1 & 6 & 4 & 7 & 1 & 18 & 12 \\
\hline Lamium $s p$ & 4 & 11 & 18 & 21 & 10 & 17 & 32 & 49 \\
\hline Lapsana communis & 2 & 0 & 4 & 0 & 4 & 0 & 3 & 0 \\
\hline Myosotis arvensis & 0 & 0 & 0 & 1 & 1 & 4 & 0 & 0 \\
\hline Sonchus sp & 0 & 0 & 4 & 0 & 1 & 0 & 1 & 1 \\
\hline Stellaria media & 7 & 1 & 9 & 1 & 14 & 63 & 28 & 116 \\
\hline Viola arvensis & 0 & 0 & 1 & 1 & 1 & 5 & 1 & 1 \\
\hline Other & 1 & 0 & 1 & 1 & 18 & 25 & 14 & 22 \\
\hline Total & 96 & 44 & 131 & 81 & 152 & 294 & 204 & 364 \\
\hline
\end{tabular}


(crop sequence A) or ten (B) different weed species were observed, the number in organic cropping being 14 (C) or 17 (D), respectively.

\section{Biomass of cultivated crops}

The comparisons between the biomasses of the cultivated crops were most successful in the years when the same crop species was cultivated on all plots. In 1982, 1988 (phase a) and in 1985 (phase b), barley was the cultivated cereal. In 1986 (a) and 1983 (b), winter wheat was cultivated in all rotations except in the barley monocultures (A1).

In the beginning of the trial, the biomasses of barley were from two to three times higher in conventional cropping than in organic cropping (Table 5). Later on, the biomasses in conventional cropping were from fivefold to sixfold higher.

The biomasses of winter wheat stands in organic cropping were only slightly less than in conventional cropping.

\section{Discussion}

The number of weeds and the dry matter yields of weeds were higher in organic cropping than in conventional cropping. The growth of weeds was best suppressed by the perennial leys. In conventional cropping, the effect was still observed in the third year ley because the nitrogen-fertilised grass ley did not grow essentially thinner when aging.

Organically cultivated clover ley suppressed weeds in the first ley year as well as conventionally cultivated grass ley. Overwintering damages in clover leys forced the use of an- nual ley crop species in the following ley years; the ley was supplemented with additional seed only in 1987. Because of its slow initial growth, clover competed poorly against the weeds, and weeds overran the clover leys.

The green manure crops in crop sequence C (85/88), too, could not compete successfully with the weeds. The crop species and cultivars sown in green fallows did not suit the local growing conditions as well as expected.

Earthing up the potato bench in crop sequence $C(84 / 87)$ clearly decreased the number of weeds. The weeds on the top of the potato bench, however, were not destroyed. The weed biomass was still high because of the weak shading of the potato stand.

The number and dry weight of weeds in winter wheat were similar in organic and conventional cropping. This can be explained by the shade effect of winter wheat stands. The biomass of wheat in organic cropping was up to three-fourths of that in conventional cropping. It is evident that, because of its long growing time, winer wheat can use the mineralized nutrients in proportion better than species sown in spring.

In the later stage of the crop rotation, barley biomasses in organic cropping were only one-fifth of the conventional cropping, and barley could not compete with the weeds in organic cropping. It was also observed that the number of weeds increased in organic cropping when there were several spring-sown cereals in succession. Preserving the fertility in organic cropped fields seems to be the most important question for successful cropping, and also has an effect on the weeds.

Table 5. Biomasses of cultivated crops (dry matter kg/ha) in conventional and organic cropping in $1982-1988$. For crop sequences a to $d$ and years, see Table 1 .

\begin{tabular}{lrrrrrrrr}
\hline Years & 82 & $83 / 86$ & $84 / 87$ & $85 / 88$ & $86 / 83$ & $87 / 84$ & $88 / 85$ & $x$ \\
\hline Conventional & & & & & & & & \\
A & 2860 & 5670 & 4220 & 4030 & 6590 & 5870 & $4020^{\text {b }}$ & 4750 \\
B & 1700 & 1550 & 4640 & 860 & 7530 & 5560 & $3350^{\text {b }}$ & 3600 \\
Organic & & & & & & & & \\
C & 800 & 3710 & 910 & 790 & 4810 & 4070 & $840^{\text {a }}$ & 2280 \\
D & 1070 & 900 & 750 & 980 & 4360 & 2700 & $750^{\text {a }}$ & 1640 \\
\hline
\end{tabular}


The number of weeds in conventional cropping was, on average, 94 weeds $/ \mathrm{m}^{2}$, and being 324 weeds $/ \mathrm{m}^{2}$ in organic cropping. Later on in the crop rotations, in organic cultivated barley stands there were from 505 to 558 weeds $/ \mathrm{m}^{2}$. In a spring cereal study (MuKULA et al. 1969), the number of weeds was $550 / \mathrm{m}^{2}$, being similar to the number of weeds in organic cropping reported here. In another study (ERviö and SALONEN 1987), the number of weeds in conventionally cultivated spring cereal fields was, on average, 173 weeds $/ \mathrm{m}^{2}$. The weed samples in the experiments cited above were taken from unsprayed areas. In a large survey of organic farming in Finland (Mela 1988), the number of weeds in spring and winter cereals was, on average, $505 / \mathrm{m}^{2}$.

In this experiment the biomass of weeds, which may reflect the competition ability better than the number of weeds per square metre, in conventional cropping was, on average, $61 \mathrm{~kg} / \mathrm{ha}$ being $425 \mathrm{~kg} / \mathrm{ha}$ in organic cropping. In organically cultivated barley stands, the dry weight of weeds was about 300 $\mathrm{kg} / \mathrm{ha}$. According to MuKula et al. (1969), the biomass of weeds in spring cereals was as much as $1000 \mathrm{~kg} / \mathrm{ha}$. ERviö and SALONEN (1987) reported the air dry weights of the weeds to be $320 \mathrm{~kg} / \mathrm{ha}$ in conventionally cultivated spring cereal fields. In the survey of alternative agriculture made by Mela (1988), the biomass of weeds in spring and winter cereals was $525 \mathrm{~kg} / \mathrm{ha}$.

The biomass of weeds in the present investigation was quite small. Because of the different sampling times it is, however, difficult to make comparisons between the above cited investigations and the present investigation.

All possibilities for controlling weeds allowed in organic cropping, such as stubble cultivation, delayed sowing and shoot cultivation, were not used in this investigation. The amount of weeds could perhaps be further decreased with these methods in some growing conditions. There is, however, not enough knowledge of the methods best suited to different conditions.
The yield reduction caused by weeds was not studied in this investigation. According to Suomela and PaAtela (1962), the average $740 \mathrm{~kg} / \mathrm{ha}$ dry weight of weeds decreased the grain yield of spring cereals between 6 to $9 \%$. Weed control using herbicides increased the cereal grain yields from 2 to $3 \%$ (SALONEN and ERVIÖ 1986) when the air dry weight of weeds was about $320 \mathrm{~kg} / \mathrm{ha}$ (ERVIÖ and SALONEN 1987).

In the present investigation, the yield reduction of spring cereals in organic cropping can be estimated from the figures presented above to be about $5 \%$. It is, however, noteworthy that the cereals in the experiments cited above had been fertilised, and thus they had more nutrients available than cereals in organic cropping. The barley yields were rather small in this investigation (see KorVA and VARIS 1990). The reduction of yields caused by weeds may have been considerably greater than estimated here because weeds competed with cultivated crops for the very sparse nutrient sources.

The weed problem in organic cropping is, however, of minor importance when compared to the differences in crop yields between organic and conventional cropping (see KoRVA and VARIS 1990). Some unpredictable conditions may, however, lead to real weed problems. Such conditions occur, for instance, when poor crop stands that have suffered overwintering damages cannot be strengthened or made dense with nitrogen fertilisers and the competing weeds cannot be destroyed by herbicides.

Preservation of the fertility of the field, use of varied crop rotations and choosing the appropriate species and cultivars best suited to local growing conditions are the basic requirements for successful weed control in organic cropping.

Acknowledgements. I would like to thank Jukka Korva for the statistical analyses and Prof. Eero Varis and Visa Nuutinen for commenting on the manuscript. 


\section{References}

Ervio, L.-R. \& Salonen, J. 1987. Changes in the weed population of spring cereals in Finland. Ann. Agric. Fenn. 26: 201-226.

HannukKala, A.O., Korva, J. \& Tapio, E. 1990. Conventional and organic cropping systems at Suitia I: Experimental design and s maries. J. Agric. Sci. Finl. 62: 295-307.

Korva, J. \& VARIS, E. 1990. Conventional and organic cropping systems at Suitia II: Crop growth and yields. J. Agric. Sci. Finl. 62: 309-319.

MELA, T. 1988. Luonnonmukainen peltoviljely Suomessa. Viljelymenetelmăt, rikkakasvit, peltojen viljavuus, sadot ja sadon laatu. Summary: Organic farming in Finland. Cultivation methods, weeds, soil fertility,

\section{SELOSTUS}

\section{Suitian viljelyjärjestelmät \\ V: Rikkakasvit}

\section{Raimo Kauppila}

Helsingin yliopisto, Kasvinviljelytieteen laitos

Vuosina 1982 - 1988 tutkittiin sekă tavanomaisesti ettă luonnonmukaisesti viljeltyjen kasvintuotanto- ja kotieläintuotantotilojen erilaisten viljelykiertojen rikkakasvustoja.

Luonnonmukaisen viljelyn viljelykiertojen rikkakasvien lukumăărăt ja kuiva-ainesadot (keskimäărin $324 \mathrm{kpl} / \mathrm{m}^{2}$ ja $425 \mathrm{~kg} / \mathrm{ha}$ ) olivat merkitsevästi suuremmat kuin tavanomaisessa viljelyssä (keskimäärin $94 \mathrm{kpl} / \mathrm{m}^{2}$ ja $61 \mathrm{~kg} / \mathrm{ha}$ ). Văhiten rikkakasveja oli tavanomaisen viljelyn nurmessa. Luonnonmukaisen viljelyn apilapitoinen nurmi ehkäisi ensimmåisenă nurmivuotena rikkakasvien kasvua yhtă hyvin kuin tavanomaisen viljelyn heinănurmi. Luonnonmukaisen viljelyn nurmien talvehtimisen epäonnistuminen lisăsi rikkakasvustoja huomattavasti seuraavina nurmivuosina. yields and yield quality. Helsingfors University, Department of Crop Husbandry. Publications 220.

Mukula, J., RaAtikainen, M., Lallukka, R. \& RaAtikalNEN, T. 1969. Composition of weed flora in spring cereals in Finland. Agric. Fenn. 8:61-110.

SAlonen, J. \& ERvıö, L-R. 1986. Kannattaako kevătviljan kemiallinen rikkakasvintorjunta. Koetoim. ja Käyt. 43: 26.

Suomela, H. \& PaAtela, J. 1962. The influence of irrigation, fertilizing and MCPA on the competition between spring cereal weeds. Weed Research 2: 90-99.

Ms received April 2, 1990
Luonnonmukaisesti viljelty syysvehnäkasvusto, jonka biomassa oli noin $3 / 4$ tavanomaisesti viljeltyyn verrattuna, văhensi sekă rikkakasvien lukumääräă että painoa lähes kuten tavanomaisesti viljellyt syysvehnäkasvustot. Ohran biomassa oli luonnonmukaisen viljelyn viljelykiertojen myöhäisessă vaiheessa ainoastaan noin $1 / 5$ ja rikkakasveja oli noin viisinkertainen määră tavanomaisesti viljeltyyn ohraan verrattuna.

Vuoteen 1988 mennessă olivat tavanomaisessa viljelyssä lähes kaikkien rikkakasvilajien lukumäärät vähentyneet tai pysyneet muuttumattomina. Luonnonmukainen viljely lisăsi useimpien rikkakasvilajien lukumäăräă vuoteen 1982 verrattuna. Eniten lisaăntyivăt Stellaria media, Fallopia convolvulus, Lamium sp ja Chenopodium album. 